\title{
An Historical Review from Exclusion to Inclusion in Western Australia across the Past Five Decades: What Have We Learnt?
}

\author{
Dianne Chambers ${ }^{1, *}$ and Chris Forlin ${ }^{2}$ \\ 1 School of Education, The University of Notre Dame Australia, Fremantle 6160, Australia \\ 2 International Education Consultant, Perth 6000, Australia; chrisforlin@outlook.com \\ * Correspondence: dianne.chambers1@nd.edu.au; Tel.: +61-8-9433-0170
}

Citation: Chambers, D.; Forlin, C.

An Historical Review from Exclusion to Inclusion in Western Australia across the Past Five Decades: What Have We Learnt? Educ. Sci. 2021, 11, 119. https://doi.org/10.3390/ educsci11030119

Academic Editor: Garry Hornby

Received: 1 February 2021

Accepted: 7 March 2021

Published: 11 March 2021

Publisher's Note: MDPI stays neutral with regard to jurisdictional claims in published maps and institutional affiliations.

Copyright: (c) 2021 by the authors. Licensee MDPI, Basel, Switzerland. This article is an open access article distributed under the terms and conditions of the Creative Commons Attribution (CC BY) license (https:// creativecommons.org/licenses/by/ $4.0 /)$.

\begin{abstract}
Current practices regarding inclusive education vary enormously depending on a wide range of issues, specifically the context and culture of an education system. To maximise the validity of data, and to avoid contextual confusion, this review focuses on one state in Australia, that of Western Australia. By applying a review of five-decade archival data, changes to education for learners with disability in this state are critiqued. Analysis involved applying five a priori themes to review educational reform practices. These were related to legislation and policy, support, curriculum, teacher education and parental choice. Discussion teased out the impact of these changes on the competing paradigms of special and inclusive education, and models and challenges of implementing effective inclusive practice for all learners in one Australian state. Critical reflection provides valuable insight into futures planning for all educational systems to reform practice to become more inclusive.
\end{abstract}

Keywords: Western Australia; inclusive education; disability; policy; curriculum; teacher education; parental choice

\section{Introduction}

There is little doubt that in most countries changes in the education of learners with disability have been highly noticeable and have altered significantly across the past half century. With the general exemption of less developed countries, where change has been fraught with a range of other local challenges, most countries now have well-established processes for supporting learners with disability. These changes have been underpinned by international declarations and conventions emanating from agencies such as UNESCO and UNICEF and local country legislation and policy. Since the 1980s, the internationally accepted philosophy of education has been to work towards a more inclusive approach to education. Commencing with an integrative model, then moving towards an inclusive approach, this has been considered as the most equitable way to educate all learners, including those with disability.

This has, nonetheless, not been an easy model to implement. Countries vary enormously in their cultural diversity and in their ability to respond to inclusion [1]. Local beliefs, values, attitudes and knowledge about children with disabilities and their needs similarly vary immensely and are frequently firmly embedded within local historical contexts making change difficult [2]. All these impact on the ability of different systems to provide appropriate and effective education opportunities and support for learners with disability.

A major area of concern in most systems has been how to effectively prepare teachers for their changed role. Considerable research has found that general education teachers continue to blame their lack of appropriate pre-service preparation for their unwillingness to be involved with inclusive education, or the difficulties they face with implementing it [3]. This finding has led to many systems developing new models of teacher preparation with greater collaboration between teacher training institutions and schools $[4,5]$. In some regions, such as Australia, the training required for all teachers to support learners with 
disability has been legislated through a set of education standards. The nationally administered Australian Qualifications Framework [6], stipulates the standards to be achieved for teachers on completing their preservice training. In Australia, most students with special educational needs are now included in regular classes. Across all systems, though, a range of schooling options continue to be offered, especially for students with high and profound support needs [7]. In less developed countries, teacher preparation remains a major concern with reported poor-quality and overall lack of general trained teachers, often large class sizes, teaching being a less desirable career, minimal support, and inadequate infrastructure and resources [1].

Linked with teacher knowledge about teaching learners with disability is the issue of curriculum. Initially, only students who were able to keep up with the regular curriculum could be included in mainstream schools. More recently, it is generally accepted that curriculum adaptation is necessary to enable access for learners with disability. While the content and expectations of achievement remain like their peers, access to or presentation of the curriculum will most likely require modification [8].

The increased involvement of parents in their child's schooling has also changed the teacher-parent relationship in many systems and increased school accountability [7]. Although it was parent advocacy in the 1970s that led to educational acceptance for learners with disability, it is only in more recent years that governments have acknowledged the rights of parents and actively encouraged them to participate in school-based decision making.

\subsection{Australian Education System}

Australia has both federal and state/territory education systems. As overall responsibility for education is decentralised to the states and territories, each jurisdiction is responsible for setting its own education Acts, policy and directions. There remains, however, some influence at a national level. The Australian Government Department of Education, Skills and Employment [9] is responsible for the development of national policies and the provision of programs for early childhood and higher education. It also provides additional funding to states and territories to support learners with disability to access primary and secondary schooling. This national funding is allocated through a process of data collection called the Nationally Consistent Collection of Data on school students with disability (NCCD). Information collected through this process determines the number of students requiring additional funding at four different levels of need:

- Support provided within quality differentiated teaching practice (no federal funding allocated),

- Supplementary adjustments,

- Substantial adjustments, and

- Extensive adjustments.

The Australian Government calculates the students with disability loading in recurrent funding. This funding is allocated directly to individual Education Departments for children attending government schools, or to Catholic Education systems, and directly to schools that are registered as Independent.

\subsection{Research}

To gain an understanding of how education systems have managed the change from minimal or no education for learners with disability through to inclusion, this research considered an in-depth review of one system in Australia. It was envisioned that the challenges in providing an overview of change in more than one system would result in limited validity with far too many differences to make any assumptions about how the move towards inclusion had really impacted on a region. This review, therefore, aimed to investigate the impact of cultural, political, social and historical changes for learners with disabilities in the state of Western Australia. 


\section{Method}

An historical perspective was provided through a review of relevant documentation and artefacts across the past five decades in Western Australian education. Documented evidence from national and state legislation and policies was critiqued. Data from published research and reports were extracted from the literature in relation to impacting on educational reform practices in the education of learners with disability. Data were obtained from educational archives, published research, historical books, national and local education reports, committee minutes, Education Acts and legislation. A number of article databases were accessed including EBSCO, A+Education, Education Source, ERIC and Google Scholar. Keywords used in a variety of combinations included: inclusion, special needs, education, Western Australia, WA, legislation, policy, teachers, teaching, pedagogy, curriculum, support, services, environment and parent/s. Literature was included in the paper if it had relevance to the time periods under consideration and was specific to the Australian or Western Australian context. Additional gray literature (including legislation) was located using internet search engines, and through use of the authors own reference collections.

Data were analysed using five a priori themes [10], extracted from the literature in relation to impacting on educational reform practices in the education of learners with disability. These themes were:

1. Policy and legislation;

2. Support and environment/learning spaces;

3. Curriculum;

4. Teachers, teacher training and pedagogy;

5. Parental choice.

\section{Definitions}

In Western Australia, the use of the term 'handicapped' was the practice in the 1970s and this was defined as "A person whose physical and/or mental well-being is temporarily or permanently impaired, whether congenitally or through age, illness, accident, or socioeconomic conditions or by an emotional-behavioural disorder, with the result that his self-dependence, schooling, or employment is impaired" [11] (p. 202).

The definition of the term disability in this paper is the one used in the most current School Education Act (1999) of Western Australia, which identifies disability as:

(a) "attributable to an intellectual, psychiatric, cognitive, neurological, sensory or physical impairment or a combination of those impairments; and

(b) which is permanent or likely to be permanent; and

(c) which may or may not be of a chronic or episodic nature; and

(d) which results in (i) a substantially reduced capacity of a person for communication, social interaction, learning or mobility; and (ii) the need for continuing support services" [12] (Part 1, Section 4, p. 4).

\section{Findings and Discussion}

Each a priori theme was considered for changes across three timeframes (1970s to early 1980s; late 1980s to early 2000s; and mid-2000s to end of 2020), covering the past half century of education for learners with disability in Western Australia.

\subsection{Theme 1: Policy and Legislation}

\subsubsection{Timeframe 1970s-Early 1980s}

Following the introduction of the normalisation principle by Wolfensberger in the Scandinavian countries in 1972 [13], worldwide philosophies for the education of learners with disability began to change intensely. From a rights-based perspective, a strong movement began to encourage learners with disabilities to be educated in regular schools. A key early influence was Public Law 94-142 [14] which in 1975 legalised the structure 
needed to implement a policy of integration in the USA. This law was widely seen as the foundation for change and, supported by the Warnock Report in the UK in 1978 [15], these were utilised by many countries internationally, including Australia, to inform local policy development.

Prior to the 1970s, education was not a right for children with disabilities in Australia. Groups such as the Australian Council for Rehabilitation of Disabled (ACROD), however, began to stimulate increasing interest in the development of special education throughout the 1960s. A Senate Standing Committee on the education of the handicapped (the term used at that time) led to the establishment of an Interim Committee for the Australian Schools Commission. One of the major foci of this Committee was "the particular needs of schools for the handicapped, whether mental, physical or social" [16]. Two key recommendations on special education requirements that emerged from this Report were (1) the need for early identification and intervention providing professional support to parents and siblings of children with handicaps, and (2) adequate training of teachers in sufficient numbers through pre- and in-service training [17]. By 1974, the Federal Government had committed extensive funds to support education including special education and teacher development. A specific grant was made during 1973 for the employment of 50 additional college academic staff at teacher training colleges to support the number of students undertaking courses in special education.

With this increased focus on the needs of learners with disability, national and local policy began to refer to the integration of children with handicaps into the education system. By the end of the decade, it was expected that all students, including those with high support needs, should be included in an education facility, with an emphasis on integration wherever possible. Although many students were still being offered placement in a segregated special school in Western Australia, this was still an improvement from previously when these children were not in education at all but placed in Activity Centres or asylums.

In the early 1980s in Australia, a noticeable move towards the integration of learners with disability was becoming well established. At this stage, though, the Education Act 1928-1970 of Western Australia [18] did not contain any definition of disability and referred only to children with disability in the context of placement options. This was not added until the new Act was enacted in 1999. Reports on progress of integration in Australia, nevertheless, were not very favourable. The Western Australian Beazley Report in 1984 [19] concluded that school sites were not adequately meeting the needs of learners with disability, but retained the perspective that if including students with disability in regular classes the children with whom they were to be included were not to be affected adversely. At a national level, the Gow Report [20], in the following year, found that while the concept of integration was commendable, the problems associated with implementation were impeding its progress. At this stage, while all jurisdictions in Australia expressed some commitment to integration in principle, there was no legal mandate to formalise this integration. Decisions regarding the inclusion of learners with disability in regular schools relied on local school choices.

\subsubsection{Timeframe-Late 1980 s to Early 2000 s}

From the late 1980s, greater attention internationally was given to addressing inequalities in education and the community. While not specifically focusing on students with disability, at Jomtien, Thailand in 1990, the United Nations Educational, Scientific and Cultural Organization (UNESCO) World Conference on Education for All [21], noted that access to basic education for all should be a focus for all countries. This declaration was the forerunner of subsequent powerful agreements impacting the education of students with disability which were signed and ratified by many countries around the world. Of particular importance to the global special education community was the 1994 release of the Salamanca Statement and Framework for Action on Special Needs Education [22]), which was a consensus of direction on education for students with disability; informed by the 
principle of inclusion with the aim of making all schools more effective. Key elements consisted of inclusion of all, celebration of individual differences, and appropriate response to the needs of all students.

In Australia, 1992 saw the introduction of the Disability Discrimination Act (DDA) [23], which stated that students with disability must receive an appropriate education without discrimination as a result of their disability. At this stage there was a transition to using the term inclusion in policy although in reality the method employed was still very much an integrated approach. In 1993, the Shean Report [24] reviewed the equity of services provided to learners with disability in Western Australia. In this report it was argued that "... inclusion is not appropriate for all children" (p. 79), and placed importance on “... retaining the existing range of placement options" (p. 98).

Unlike the previous 1928 Education Act, the new 1999 School Education Act of Western Australia [12] (Part 1, Section 4) included a definition of disability identifying it as meaning a condition:

(a) "which is attributable to an intellectual, psychiatric, cognitive, neurological, sensory or physical impairment or a combination of those impairments; and

(b) which is permanent or likely to be permanent; and

(c) which may or may not be of a chronic or episodic nature; and

(d) which results in-

(i) a substantially reduced capacity of a person for communication, social interaction, learning or mobility; and

(ii) the need for continuing support services"' (p. 4).

The definition provided some clarity around the identification of students with disability but was broad and conversely, could be used to exclude students from receiving support if they did not meet the definition; particularly students with specific learning disability.

By early 2000, all states and territories had developed their own policies on services for learners with disability. Inclusive education was viewed as an essential component of social justice and the provision of equitable access to schooling. Policy statements reflected the DDA, although implementation varied significantly depending upon systemic regional and local personnel and financial resources.

\subsubsection{Timeframe-Mid-2000s to End of 2020}

During this time frame, strong legislation introduced in the USA also had an impact on other countries around the world, including Australia. The introduction of the Individuals with Disabilities in Education Amendment Act 2004 (IDEA) [25], superseded Public Law 94-142 [14] and ensured services to children with disability in the USA through early intervention, special education and appropriate services.

Internationally, the Convention on the Rights of Persons with Disabilities [26] also had a significant influence on the way that the rights of people with disability were viewed, not only in education, but in society. Article 24 specifically addressed education and clearly stated that persons with disability must have access to inclusive education on an equal basis with others in their community and that they are to be provided with accommodations and supports to be successful. Australia was an early signatory to the Convention on the Rights of Persons with Disabilities (CRPD).

Sitting under the DDA (1992) in Australia, the national Disability Standards for Education (DSE) were enacted in 2005 [27], developed to make explicit to education providers and consumers their rights and responsibilities in relation to students with disability. The DSE required that all education providers ensured enrolment in appropriate settings, access to curriculum, participation in educational activities, provision of support services and that students with disability were not victims of harassment. These standards were wrapped around concepts of reasonable adjustments in the classroom, and access on the same basis as peers. The DSE was significant legislation as it provided guidance for both teachers and parents regarding suitable accommodations and adjustments for students with disability in the classroom. In Western Australia, in the current educational environment, 
educational bodies rather than individual schools, provide guidance to teachers and parents on inclusive education through policies at a sector level which incorporate legislative requirements. Even though Australia now has national policies on education promoting inclusion, and anti-discrimination Acts aimed to ensure the rights of children and youth to inclusive schooling, access to inclusion still varies considerably between government and non-government systems, jurisdictions, regions, and local schools. Inclusion is a focus in policy but in reality, it remains an option within a continuum of placements.

\subsection{Theme 2: Support and Environment/Learning Spaces}

\subsubsection{Timeframe-1970s to Early 1980s}

By the early 1970s, like many other countries, a fairly comprehensive dual system of education had been established in all states and territories in Australia. Categorical special schools for students with a range of specific disabilities had emerged so that students were educated with those with similar disabilities. Such schools were autonomous in their management and situated on separate sites from regular schools. Class sizes were generally between five and 15 students depending upon their specific needs. Where available, special education-trained teachers were employed and supported by a range of unqualified teacher aides.

In Western Australia, the late 1970s saw the establishment of socio-psycho-educational resource centres (SPER centres). Not designed as special schools (although acting in a remarkably similar vein), they were provided as an alternative school to give temporary support to learners who were not coping with the demands of regular schools. Finding the inclusion of some learners in regular schools to be challenging due to failing to "... produce acceptable behavioural responses to the normal classroom setting despite efforts by the teacher with assistance from a variety of sources" [28] (p. 15), they were offered placement in a SPER centre. This placement could be up to two years before they were expected to be integrated back into their local school.

Regular primary and secondary schools mainly enrolled students without disability, although students with learning difficulties were included by default and when identified usually separated into remedial classes. Class sizes were relatively large, usually between 30 and 40 students. There was no expectation that students in the remedial classes were to complete the regular curriculum. Towards the end of the decade, the philosophy of segregated education for students with disability had been challenged and a movement towards reintegrating these students back into regular schools had commenced. The concept of social inequality and empowerment was introduced.

\subsubsection{Timeframe-Late 1980s to Early 2000s}

The movement away from placement of children with disabilities in segregated facilities to greater inclusion in regular schools dramatically changed the nature of special and regular education during this period. The integration into regular schools initially focused on learners with mild disability, although it was widely acknowledged that the role of regular teachers would still need to change.

This movement resulted in a continued debate about how regular schools could best support these learners. Several major publications referring to widespread community consultations concluded that provision of the level of support needed in terms of personnel and facilities to ensure the safety and hygiene of learners with disability was beyond reasonable expectations for regular schools $[29,30]$. They further concluded that any gains obtained by including learners with high support needs would be outweighed by the disadvantages and would be detrimental to existing students.

To resolve this issue, most jurisdictions reviewed existing support structures and aimed to establish ways to provide some middle ground between special and regular schools. In Western Australia, several environmental changes were made. Following the Beazley Report, a new policy 'Changes to Services for Children in Need of Educational Support' in1984 [31], outlined significant changes to the existing organisation of govern- 
ment services. Newly established Education Support Centres were designed to cater for students with mild to moderate disabilities. While autonomous with their own principal and teaching staff, these centres were placed on site of regular school buildings with the intention to help promote increased opportunities for their students to participate in regular class activities. Where there was insufficient need for a centre, individual Education Support Units were provided within regular schools, consisting of one or two classes under the management of the regular school.

In addition, schools began to employ increasing numbers of unqualified education assistants to support teachers, especially when including learners with disability into regular classes. The role of the assistants commenced by withdrawing students for individual or small groupwork, but gradually began to move more towards working with students within the regular classroom.

Inevitably, some special schools were closed, and the teachers became support teachers in regular schools. The degree of involvement of learners with disability from the Education Support Centres or Units in the onsite regular schools, however, varied enormously as it was dependent upon the relationships between the two principals and the ethos of both schools. Although the Education Department had established a policy that supported inclusion, based on the recommendations from the Shean Report and the existing Education Act, it simultaneously retained the right to prevent the inclusion of students deemed unsuitable. The education policy in 1993 [32] stated that where three criteria of significant deficits in (a) adaptive behaviour; (b) academic achievement; and (c) intellectual functioning of two or more standard deviations below the mean, were met, students were still eligible for placement in education support facilities.

\subsubsection{Timeframe-Mid-2000s to End of 2020}

While the inclusion movement in education was still gaining momentum during this period, the continuum of services offered to students with disability remained in place. There were education support centres and special schools available for students to access, and some specialised language development centres, and centres catering for students with specific disability, such as Autism Spectrum Disorder [33]. Along with the existing provision, purposeful planning of new schools began incorporating a composite model. Instead of building a separate, segregated school or centre, these are now being merged in the planning and building of the school (both primary and secondary sites), known as a One School Model [34]. These specially designed settings include appropriate modifications and accommodations to the physical environment to address the needs of all potential learners, in line with the Disability Standards in Education 2005 [27]. Modifications may include lifts (in multi-story sites), ramps, wide-opening doors for access, large class sizes, modified furniture, toilet facilities, and access to technology.

In 2011, a panel review of school funding in Australia, known locally as the Gonski Report, revealed large gaps and inequities between students, with differences in educational outcomes, often attributed to differences in social economic factors and community position [35]. The panel concluded that " ... every child should have access to the best possible education, regardless of where they live, the income of their family, or the school they attend" (p. xiv). The report stated that the best way to achieve equity was through funding reform, and a new model of increased school funding was suggested, including greater clarity around individual state and federal funding. The new model suggested funding per student, with an additional load for students with disability. As jurisdictions across Australia used different definitions for disability, it was also determined that a Nationally Consistent Collection of Data on School Students with Disability [NCCD] [36] would take place annually to determine the number and level of adjustments provided to students with disability. From 2018, funding for students with disability from the Australian Government has been based on the NCCD data.

Beginning in the mid-2000s, there was an emphasis in the education system on decentralisation in order to ensure local requirements could be met in schools. The decentrali- 
sation involved a move from centralised special education consultants to district support groups, which could be more responsive to schools and gain a deeper understanding of the issues for schools in different geographic areas. As part of the decentralisation of education support, Independent Public Schools (IPS) were introduced [37], where schools could apply to be independent, and work from a one-line budget. This form of budgeting allowed schools to make individual decisions about how and where the funding would be best applied in the school to meet the needs of all learners. The IPSs included regular schools, education support centres and education support schools and required a school board to be formed to assist with the operations of the school. The IPS system allowed schools to hire staff as required, for example, social workers or speech pathologists, who may not normally be part of the school's regular staff.

\subsection{Theme 3: Curriculum and Pedagogy \\ 3.3.1. Timeframe-1970s to Early 1980s}

In the 1960s and 1970s, state-based education departments in Australia began to develop special schools to accommodate students with disability. In regular schools the curriculum that was expected to be taught to students was also state based and detailed in regards to the content and when it was expected to be covered, which was not always accessible for students with disability. In special schools, specific curriculum was developed by individual schools, often with a life-skill focus, to support students in gaining appropriate daily living skills such as self-care, money concepts, and travel skills. The main aim of many of the life-skill curricula was to assist the students to be active members of society and potentially access the workforce on leaving school. Some commercially available programs were used by some special schools, such as the Walker Social Skills Curriculum [38].

\subsubsection{Timeframe-Late 1980s to Early 2000s}

Outcomes-based education (OBE) became a popular educational approach in Western Australia around the 1990s [39]. While this approach was said to be useful as it examined the outputs of curriculum and then moved backwards through curriculum design, there were many issues with the implementation of this approach in schools in WA. Berlach and McNaught describe the difficulties with the implementation of an outcomes-based curriculum as being poorly handled by education authorities. The documentation was convoluted and difficult to comprehend, assessments were time-consuming and insufficiently competitive and, of most concern, the underlying philosophy of OBE was incompletely considered. Teachers were dissatisfied with the OBE system and an unprecedented loss of experienced teachers from the system was reported. The use of outcomes to measure student progress was promoted for all students, including students with disabilities. The OBE approach was discontinued in 2008 in Western Australia with the reintroduction of a K-10 Syllabus.

\subsubsection{Timeframe-Mid-2000s to End of 2020}

A unified Australian curriculum was released in 2010 to be used by all states and territories in Australia [40]. There have, however, since been local state variations applied to some of the subject areas in the curriculum. In Western Australia, teachers access the School Curriculum and Standards Authority (SCSA) version of the curriculum. The WA Curriculum, as it is known, includes access to ABLEWA (Ability Based Learning Education Western Australia), an assessment tool and curriculum materials for students with disability and additional learning needs [41]. The ABLEWA provides access points to the curriculum for students who may be working at a level lower than pre-primary and therefore may not be able to access the regular curriculum levels. In addition to using ABLEWA to provide appropriate curriculum, teachers can also take a three-pronged approach to devising learning objectives for students with disability that may be drawn from one or more of three dimensions of the Australian Curriculum; the curriculum materials; general capabilities; or cross-curriculum priorities [42], although the curriculum is recommended as the starting point. 
While there is no specific requirement for the use of planning formats, or stipulation of the format to be used, the DSE [27] refers to programs taking into account the intended educational outcomes and learning needs and capacities of the learner with a disability. Most schools and educational sectors utilise individualised programs to identify and record the needs and key learning objectives for learners with a disability. There is no one standard format for these individualised programs, and examples include an Individual Education Plan (IEP), Curriculum Adjustment Plan (CAP), Individual Behaviour Management Plan (IBMP), or Developmental Learning Plan (DLP). There is an expectation that, where feasible and appropriate, special education settings will teach an adapted version of the national curriculum, through making reasonable adjustments to the instruction, curriculum and environment allowing for personalised learning and individualised support [42].

Between 2012 and 2014, support for schools in the form of an initiative titled More Support for Students with Disabilities (MSSD) was instigated for all states and territories, including Western Australia, utilising funds from the Federal government (specifically, Department of Education and Training). Independent evaluation of the initiative suggested that the objective to "... build the skills of teachers and increase school capacity to better meet the educational needs of students with disability" [43] (p. 9) was achieved well, with some obvious capacity building noted in many schools and sectors. While only a short-term initiative, the MSSD focused attention on improving the learning and educational outcomes for students with disability.

\subsection{Theme 4: Teachers, Teacher Training and Pedagogy}

3.4.1. Timeframe-1970s to Early 1980s

During this period, teachers were trained either as generalist primary or specialised secondary teachers in Australia. For teachers wanting to work in special schools, separate training was offered. Teachers expected to be able to obtain a job working in the area for which they had trained. In addition, classes were homogenised with grading of students within year groups, so that teachers would be mainly working with students of like abilities. Teachers built up expectations of achievement and behaviour within the age groups in which they taught. Most students were of Australian, Aboriginal or British descent. Teachers experienced little diversity within regular classes.

Teacher training was considered a full-time course with an expectation that they would be on site at their training college five days a week. Training for regular schools focused on generic skills based on limited theory with a stronger emphasis on practical teaching skills and strategies. At the beginning of the 1970s, teacher preservice training courses did not include any compulsory units of study on teaching students with disability. Separate courses were offered for those who wanted to prepare to teach in a special school where the greater emphasis was on teaching life skills in preparing students for living in a family and the community. By the mid-1970s, though, the main training colleges in Western Australia required all students to take special education courses in their first and second years of study. These were focused on medical issues associated with specific categories of handicap and did not provide an integrated approach. It was not until the early 1980s that training colleges offered the first additional one-year diploma in special education that was non-categorical and focused on competent teaching techniques and procedures irrespective of medical condition.

Pedagogy remained didactic, teaching to the average of the class with limited modifications, especially for learners who were gifted or deemed to be 'slow learners'. Desk layout was rigid with students placed in rows and classes grouped according to ability. It was not uncommon for the brightest students to be placed in the front rows and the weaker ones at the back of the classroom.

\subsubsection{Timeframe-Late 1980s to Early 2000s}

As inclusive education gained momentum in Australia, teachers voiced increasing concerns about their inability to provide for learners with disability. Many questioned the 
appropriateness of inclusive education. There was little evidence to support this inclusion from an academic standpoint, although it was generally perceived that it had social gains.

Teachers voiced fears about being judged on their abilities if they were unable to support learners with disabilities, especially those that exhibited particularly challenging behaviours. They cited a lack of training, large class sizes, disruption to their regular teaching, parents of learners without disability being unaccepting of inclusion and their frustration in being unable to cope with the new challenges. At this stage including learners with a disability in a regular classroom was not mandated in Australia and so many teachers opted out.

\subsubsection{Timeframe-Mid-2000s to End of 2020}

With the strengthening of expectations around inclusive education, teachers began to experience teaching more students with disability in regular classes, and this is now considered the norm and is legislated. While recent research reports that teachers still complain about being unprepared to teach students with disability, teacher education programs require courses in the area of special/inclusive education in order to achieve accreditation as a university program [44] and to meet graduate teacher standards. Training for teachers, however, does not always allay concerns [45], and crowded university curriculums may not allow significant time for practical training, as opposed to philosophical approaches. Australian Professional Standards for Teachers [46] require that graduate teachers " ... demonstrate broad knowledge and understanding of legislative requirements and teaching strategies that support participation and learning of students with disability" (p. 11).

There is an increasing requirement that teaching practices, for all students, are evidence based and data driven to ensure the efficacy of the practice [1]. The scientific approach to teaching requires evidence that a practice actually works and is the most efficacious [47]. Individualised, student-centred learning approaches are now seen as appropriate pedagogy to address the learning needs of students [48].

\subsection{Theme 5: Parental Choice}

\subsubsection{Timeframe-1970s to Early 1980s}

Parental choice in education placement for children with disability was virtually non-existent in the 1970s. This was clearly enunciated in The Education Act, 1928-1970 of Western Australia, which although receiving minor amendments, was not repealed until 1999. In the Act, specific recommendations for children with disability were contained in Section 20A(1), covering children requiring special education and in Section 20B(1) for those with severe disorders. These sections pertain only to placement options and make it very clear that parents do not have any right to choose the placement for their child. Section 20A(1) Children requiring special education (Education Act 1928-1970) states that:

Where it appears to an advisory panel that a child of not less than 6 years of age nor more than leaving age has a mental or physical disorder or disability of such a nature that the interests of that child would be best served if he were to attend a school providing education of a kind specially suited to persons with such a disorder or disability, the Minister may, on the recommendation of the panel, serve on the parent of the child a direction in writing requiring the parent to cause the child to attend such school or schools as is or are specified in the direction during such times as are so specified (p. 38).

Section 20B(1) Children with severe disorders (Education Act 1928-1970) states that:

Where it appears to an advisory panel that a child has a mental or physical disorder or disability of so severe a nature that the presence of that child in a Government school would disrupt the normal operation of the school the Minister may, on the recommendation of the panel, serve on the parent of the child a direction in writing directing the parent to refrain from causing the child 
to attend any Government school and whilst the direction remains in force the Minister shall refuse to permit the child to attend any Government school (p. 39).

Parents who attempted to challenge such directives were invariably seen as 'troublemakers' and unwelcome in their child's school. This directive resulted in a number of children with severe disorders being unable to attend any government school.

\subsubsection{Timeframe-Late 1980 s to Early 2000 s}

Over the next period, parents became increasingly more involved in the education of their children with disability. Parent advocacy and support groups were cultivated and constituted an important and vocal voice in promoting and advocating for inclusion. These were frequently supported by Non-Government Organisations (NGOs). Family-centred services became common for children with disabilities in the $0-5$ age group, and more funding and support services were made available by the states and territories and NGOs to encourage early intervention.

\subsubsection{Timeframe-Mid-2000s to End of 2020}

Decisions about placement in a specific educational setting are now made with significant input and choice from parents, and any disputes about the feasibility of the placements are addressed by an advisory panel who guides the Director General about education placement [49]. Parents have much greater input into the educational planning for their children, often in the form of an Individual Education Plan (IEP), which is a collaborative document detailing the key goals and objectives to be met by the child. As parents have significant knowledge of their children's abilities and needs, they are logical and necessary partners in the educational process [50]. Parents also have heightened knowledge of process and procedures involved in the schooling system and their rights in relation to the Disability Discrimination Act [23] and Disability Standards for Education [27], due to the increased access to online information.

With the initiation of Independent Public Schools, parent representation on school boards is now a commonplace and expected occurrence. This representation provides further impetus for parental input into the school's objectives, priorities and general policy directions [51]. All schools have a website where information about the school is readily available.

Parental choice in relation to therapy has grown due to the implementation of an Australia-wide National Disability Insurance Scheme (NDIS) [52], which provides funding resources to support the needs and build independence of people with disability. Therapies may be provided during school time (in consultation with the school), and are parent controlled, rather than being fully determined by the school, as happened in the past.

\section{Conclusions}

Based on this historical perspective, through an analysis of documents and artefacts, it is possible to obtain an overall picture of how Australia, and in particular Western Australia, has transitioned from providing no education or schooling to students with high and profound support needs to making education available to all students within their local inclusive school. Mirroring international declarations, many important reforms underpinned by national legislation and local policy have led this change in Australia. The move towards inclusion for all remains, nonetheless, a movement in flux, with new amendments and opportunities being introduced through a continuous improvement regime. Australia is somewhat unique as education is governed locally within each jurisdiction but committedly supported fiscally by additional federal funding. Legislation is national, yet jurisdictions can enact their own policies without interference from a central government. Inevitably, this has led to different approaches to the education of children with disabilities, a variety of support structures, and alternative schooling arrangements across the states and territories. 
Nevertheless, the competing paradigms of special and inclusive education remain. In many ways, education reform is cyclical, in that old ways become new ones: only under new terms and embedded in different philosophies. Of key importance, though, is that all children now have access to education and no children are confined to activity centres or asylums. In reality, the range of educational placement options available continue to be the same as in the 1970s, although placement selection is now reversed. While initially movement was from segregated facilities into integrated ones, it is now from inclusive settings into more segregated ones. The names of the schools are less stigmatising and school sites expect to cater for considerably more diverse student populations, but it remains that for children with the most challenging needs, education for them is with a specialist teacher in a separate classroom.

The latest model to emerge in Western Australia for newly developing government school sites is a fully inclusive approach to physical placements for all students. Students who would have previously gone to a segregated special school, an education support centre or a mainstream school will now have the choice of attending a school that is a combination of all three options, which the Department of Education have termed a 'One School Model' [34,53]. Under this new model the designated school site will have one overarching principal, with an associate principal taking the role of supporting students with special needs. These students may be placed in the regular classroom, or in a special classroom where their needs will be best met. The One School Model has some correlation to the Inclusive Special Education theory suggested by Hornby [54], in particular the necessity for close collaboration with parents and school staff.

This new model has strong implications for the involvement of parents in decision making. From the analysis, it is evident that parental involvement in their child's education has increased significantly over the past fifty years and that it has now reached a stage where the rights of parents have been firmly embedded within Australian legislation and policies. Decisions about placement choices for learners with special education needs are made with substantial input by parents, alongside a comprehensive team of relevant stakeholders. Parents are in general more aware of and knowledgeable about options for their children and can be extra demanding about accessing these. Parents are involved in much more intensive discussions with their school, moving in advance of supporting the school through Parents and Citizens fundraising activities, to being engaged in greater decision making through participation on school boards and other endeavours that allow their voices to be heard. Accountability by schools has also increased exponentially, with a considerably greater openness about their curricula and pedagogy, and the supports that they provide to learners with special needs.

In addition to having a stronger voice in the education of students with special needs, an extensive review of the empirical literature about parental involvement and inclusive education by Afolabi [55], revealed a " ... strong and meaningful relationship between parental involvement and academic achievement and that parents' beliefs, expectations, and experiences, are important ingredients that support better learning outcomes for children" (p. 196). Establishing and maintaining an effective and positive relationship between parents and schools will, therefore, need to be an essential component of the new fully inclusive model of physical placements within the one school brand. Enacting this model will result in larger numbers of parents of learners with disabilities vying for the same outcomes and opportunities that they previously accessed within a smaller and more focused special school system.

Parents of learners with special needs do not want equal opportunities but equitable ones for their children. Inevitably, this will require schools to provide differentiated options for some learners, which may be seen by parents of learners without special needs as being discriminating against their children. It remains to be seen whether parents of learners with special needs will consider the support available within this new model reasonable and equitable compared to the facilities and supports that were previously provided in the segregated special schools. The model may also challenge parents' perceptions of whether 
their rights of choice are being enabled or constricted within a much more diverse and larger schooling organization.

Author Contributions: Conceptualization, D.C. and C.F.; formal analysis, D.C. and C.F.; methodology, D.C. and C.F.; writing-original draft, D.C. and C.F. All authors have read and agreed to the published version of the manuscript.

Funding: This research received no external funding.

Conflicts of Interest: The authors declare no conflict of interest.

\section{References}

1. Forlin, C. Best Practice Adjustments for Students with Disability: A Report for the National School Resourcing Board. 2019. Available online: https://www.dese.gov.au/swd/resources/research-report-best-practice-adjustments-students-disability (accessed on 23 November 2020).

2. Beacham, N.; Rouse, M. Student Teachers' Attitudes and Beliefs about Inclusion and Inclusive Practice. J. Res. Spec. Educ. Needs 2012, 12, 3-11. [CrossRef]

3. Forlin, C.; Chambers, D. Catering for Diversity: Including Learners with Different Abilities and Needs in Regular Classrooms. In Life in Schools and Classrooms: Past, Present and Future; Springer: Berlin/Heidelberg, Germany, 2017; pp. 555-572. [CrossRef]

4. Florian, L.; Rouse, M. The Inclusive Practice Project in Scotland: Teacher Education for Inclusive Education. Teach. Teach. Educ. 2009, 25, 594-601. [CrossRef]

5. Forlin, C. (Ed.) Responding to the Need for Inclusive Teacher Education: Rhetoric or Reality? In Future Directions for Inclusive Teacher Education; Routledge: Milton Park, UK, 2012; pp. 3-12.

6. Australian Government. Australian Qualifications Framework. 2013. Available online: https://www.aqf.edu.au/ (accessed on 24 November 2020).

7. Forlin, C.; Chambers, D. Diversity and Inclusion and Special Education. In Oxford Research Encyclopedia of Education; Oxford University Press: Oxford, UK, 2020. [CrossRef]

8. Otukile-Mongwaketse, M.; Mangope, B.; Kuyini, A.B. Teachers' Understandings of Curriculum Adaptations for Learners with Learning Difficulties in Primary Schools in Botswana: Issues and Challenges of Inclusive Education. J. Res. Spec. Educ. Needs 2016, 16, 169-177. [CrossRef]

9. Australian Government Department of Education, Skills and Employment. Schooling. 2020. Available online: https://www.dese. gov.au/schooling (accessed on 4 January 2021).

10. Miles, M.B.; Huberman, A.M.; Saldana, J. Qualitative Data Analysis: A Methods Sourcebook, 3rd ed.; Sage Publishing: Newcastle upon Tyne, UK, 2014.

11. Australian Council for Rehabilitation of Disabled (ACROD). Open Letter from Australian Council for Rehabilitation of Disabled. Aust. Occup. Ther. J. 1972, 19, 202.

12. Government of Western Australia. School Education Act 1999. Government of Western Australia. 1999. Available online: https:/ / www.legislation.wa.gov.au/legislation/statutes.nsf/law_a1960.html (accessed on 25 November 2020).

13. Wolfensberger, W. Normalization: The Principle of Normalization in Human Services; National Institute on Mental Retardation: Toronto, ON, Canada, 1972.

14. United States Congress. Education for All Handicapped Children Act. Pub. L. No. 94-142; 1975.

15. Warnock, H.M. Report of the Committee of Inquiry into the Education of Handicapped Children and Young People; Special Education Needs, Her Majesty's Stationery Office: London, UK, 1978.

16. Karmel, P. Schools in Australia: Report of the Interim Committee for the Australian Schools Commission; Interim Committee for the Australian Schools Commission: Canberra, Australia, May 1973. Available online: https://apo.org.au/node/29669 (accessed on 23 November 2020).

17. Drummond, N.W. Special Education in Australia: With Special Reference to the Developments in the Education of the Handicapped in the Decade of Rehabilitation, 1970-1980; 1978. Available online: https://download.onlinefreetrial.xyz/book/show/33 10247-FILE (accessed on 11 March 2021).

18. Government of Western Australia. Education Act 1928-1970. Government of Western Australia: Perth, Australia. 1970. Available online: https:/ / www.legislation.wa.gov.au/legislation/prod/filestore.nsf/FileURL/mrdoc_18804.pdf/\$FILE/Education\%20 Act \%201928\%20-\%20\%5B06-00-00\%5D.pdf?OpenElement (accessed on 25 November 2020).

19. Beazley, K. Report of the Committee of Inquiry into Education in Western Australia; Western Australia: Ministry of Education: Perth, Australia, 1984.

20. Gow, L. Report of the Working Party on Special Education on Commonwealth Policy and Direction in Special Education; Commonwealth Department of Education: Canberra, Australia, 1985.

21. United Nations Education, Scientific and Cultural Organisation. Final Report: World Conference on Education for All: Meeting Basic Learning Needs. 1990. Available online: https:/ / unesdoc.unesco.org/ark:/48223/pf0000097551 (accessed on 23 November 2020).

22. United Nation Educational, Scientific and Cultural Organization. The Salamanca Statement and Framework for Action on Special Needs Education. 1994. Available online: https://unesdoc.unesco.org/ark:/48223/pf0000098427_eng (accessed on 5 January 2021). 
23. Commonwealth of Australia. Disability Discrimination Act 1992. Available online: http://www.comlaw.gov.au/Details/C201 2C00110/Download (accessed on 23 November 2020).

24. Shean, R. The Education of Students with Disabilities and Specific Learning Difficulties; Report of the State Government Taskforce; Western Australia Ministry of Education: Perth, Australia, 1993.

25. United States Congress. Individuals with Disabilities in Education Amendment Act. Pub. L. No. 108-446; 2004.

26. United Nations. Convention on the Rights of Persons with Disabilities (CRPD) | United Nations Enable. 2006. Available online: https://www.un.org/development/desa/disabilities/convention-on-the-rights-of-persons-with-disabilities.html (accessed on 4 January 2021).

27. Commonwealth of Australia. Disability Standards for Education 2005. 2005. Available online: http://www.comlaw.gov.au/ Details/F2005L00767 (accessed on 4 January 2021).

28. Education Facilities in Western Australia for the Child with Special Needs; Education Department of WA: Perth, Australia, 1977.

29. Ashman, A.F.; Bayne, B.; Mangan, J. Resourcing Methodology, Resourcing Instrument, and Algorithm for Students with Disabilities and Their Schools; Report submitted to the Inclusive Education Branch, Education Queensland, Brisbane; University of Queensland: Brisbane, Australia, 2002.

30. Jenkinson, J.C. Mainstream or Special? Educating Students with Disabilities; Routledge: Milton Park, UK, 1997.

31. Vickery, R. Changes to Services for Children in Need of Educational Support: Statement of Education Department Policy; Education Department of Western Australia: Perth, Australia, 1984.

32. Ministry of Education. Policy and Guidelines for the Education of Students with Disabilities; Western Australia Education Department: Perth, Australia, 1993.

33. Department of Education. Education Support Centres and Schools. 2020. Available online: https://www.education.wa.edu.au/ education-support-centres-and-schools (accessed on 5 January 2021).

34. Department of Education. John Butler Primary College. n.d. Available online: https://www.det.wa.edu.au/schoolsonline/ overview.do?schooliD=5835 (accessed on 15 December 2020).

35. Gonski, D. Review of Funding for Schooling-Final Report. 2012. Available online: https://www.dese.gov.au/uncategorised/ resources/through-growth-achievement-report-review-achieve-educational-excellence-australian-schools (accessed on 25 November 2020).

36. Education Services Australia. What Is the NCCD? 2020. Available online: https://www.nccd.edu.au/wider-support-materials/ what-nccd?parent=/understanding-nccd\&activity=/wider-support-materials/what-nccd\&step=-1 (accessed on 15 January 2021).

37. Department of Education. Public School Councils and Boards: Information Package V. 1. 2020. Available online: https: / / www.education.wa.edu.au/dl/19872k (accessed on 5 January 2021).

38. Walker, H.M. The Walker Social Skills Curriculum: The ACCEPTS Program; Pro-Ed: Austin, TX, USA, 1983.

39. Berlach, R.G.; McNaught, K. Outcomes Based Education? Rethinking the Provision of Compulsory Education in Western Australia. Issues Educ. Res. 2007, 17, 1-14. Available online: http:/ / www.iier.org.au/iier17/berlach.html (accessed on 25 November 2020).

40. Australian Curriculum, Assessment and Reporting Authority (ACARA). About the Australian Curriculum. n.d. Available online: https: / / www.australiancurriculum.edu.au/about-the-australian-curriculum/ (accessed on 23 November 2020).

41. School Curriculum and Standards Authority (SCSA). ABLEWA-Abilities Based Learning Education, Western Australia. 2014. Available online: https:/ /k10outline.scsa.wa.edu.au/home/resources/ablewa (accessed on 16 December 2020).

42. Australian Curriculum, Assessment and Reporting Authority (ACARA). Meeting the Needs of Students with a Disability. n.d. Available online: https:/ / www.australiancurriculum.edu.au/resources/student-diversity/meeting-the-needs-of-students-witha-disability/ (accessed on 16 December 2020).

43. PhillipsKPA. Evaluation of the More Support for Students with Disabilities Initiative 2012-2014. 2015. Available online: https:/ / www.dese.gov.au/uncategorised/resources/phillips-kpa-mssd-final-evaluation-report (accessed on 4 January 2021).

44. Stephenson, J.; O'Neill, S.; Carter, M. Teaching Students with Disabilities: A Web-Based Examination of Preparation of Preservice Primary School Teachers. Aust. J. Teach. Educ. 2012, 37, 5. [CrossRef]

45. Forlin, C.; Chambers, D. Teacher Preparation for Inclusive Education: Increasing Knowledge but Raising Concerns. Asia Pac. J. Teach. Educ. 2011, 39, 17-32. [CrossRef]

46. Australian Institute for Teaching and School Leadership (AITSL). Australian Professional Standards for Teachers. 2011. Available online: https:/ / www.aitsl.edu.au/docs/default-source/national-policy-framework/australian-professional-standardsfor-teachers.pdf (accessed on 25 November 2020).

47. Forlin, C.; Chambers, D.; Loreman, T.; Deppeler, J.; Sharma, U. Inclusive Education for Students with Disability: A Review of the Best Evidence in Relation to Theory and Practice, Canberra; Government Department of Education, Employment and Workplace Relations \& Australian Research Alliance for Children and Youth: Canberra, Australia, 2013. [CrossRef]

48. Hattie, J. Visible Learning for Teachers: Maximising Impact on Learning; Routledge: Milton Park, UK, 2012.

49. Department of Education. Disabilities Advisory Panel. 2001. Available online: http://det.wa.edu.au/policies/detcms/policyplanning-and-accountability / policies-framework/policies / disabilities-advisory-panel.en?bbp.9.policyID=9835075\&bbp.s=10 \&bbp.e=select\&bbp.10.pane=0\&bbp.v=7\&bbp.i=d0.1.1.1.1.1.1.3.1.1.1.1.1\&g11n.enc=UTF-8 (accessed on 23 November 2020).

50. Kurth, J.A.; McQueston, J.A.; Ruppar, A.L.; Toews, S.G.; Johnston, R.; McCabe, K.M. A Description of Parent Input in IEP Development through Analysis of IEP Documents. Intellect. Dev. Disabil. 2019, 57, 485-498. [CrossRef] [PubMed] 
51. Department of Education. Independent Public Schools. n.d. Available online: https://www.education.wa.edu.au/independentpublic-schools (accessed on 4 January 2021).

52. National Disability Insurance Agency [NDIA]. What Is the NDIS? 2021. Available online: https://www.ndis.gov.au/ understanding/what-ndis (accessed on 15 January 2021).

53. Afolabi, Q.E. Parents' involvement in inclusive education: An empirical test for the psycho-educational development of learners with special educational needs (SENs). Acad. J. 2014, 6, 196-208. [CrossRef]

54. Collier, P. New Schools for Perth's Northern Suburbs. 2014. Available online: https:/ / www.mediastatements.wa.gov.au/Pages/ Barnett/2014/02/New-schools-for-Perth\%E2\%80\%99s-northern-suburbs-.aspx (accessed on 23 November 2020).

55. Hornby, G. Inclusive Special Education: Development of a New Theory for the Education of Children with Special Educational Needs and Disabilities. Br. J. Spec. Educ. 2015, 42, 234-256. [CrossRef] 